\title{
PATENT LICENSE AGREEMENT IN IMPROVING NATIONAL ECONOMY FEBRIYANDI \\ 155100030
}

Fakultas Komputer,448757155

febriyandi.student@umitra.ac.id

\begin{abstract}
Patent License Agreement is one form of technology transfer that can be done to cover the unavailability of technology needed in the country A license is a permit granted by a patent holder, both exclusiveor non-exclusive, to the licensee based on a written agreement for use patents that are protected within certain periods and conditions. Agreement Patent licenses play a big role in advancing the national economy. that is, as a function of government control and supervision in the field of technology, in the end it will impact on the implementation of technology transfer. Remembering the role of the licensing agreement is so large, all efforts intended to support the optimization of the implementation of patent license agreements need to be sought. The purpose of this scientific journal writing is: 1 . To find out and analyze legal protection in patent licensing agreements and their role in advancing the national economy 2. To find out and analyze forms of optimization of arrangements in patent licensing agreements so as to improve the national economy The method used is a normative juridical type, with an approach through legislation, namely Act Number 13 of 2016 concerning Patents, as well as approaches to legal concepts that can support the optimization of patent license agreements.
\end{abstract}

Keywords:Technology Transfer, Patents, License Agreement

\section{A. INTRODUCTION}

the patent definition according to Slamet Dirham, namely: A patent is basically a document issued on a patent request from an inventor by the state through the Patent Office which contains a description of discoveries as well as legal force and legal protection for the invention requested for the patent. Based on the description above, it can be stated that the patent is a special right or right exclusive given by the government to inventors or inventors in the form of documents regarding their findings in the field of technology to implement themselves or give approval to other parties to implement them. Patents are given to protect inventions in the field of technology in a limited period of time in order for the patent holder to benefit economy that is worthy of its invention. It is said to be an exclusive right because Such rights are only granted to Inventor excludes parties 
others use and implement the invention. Next in Patent Law Number 13 of 2016 also regulated regarding the transfer of rights from the technology that has been registered his patent through a licensing agreement. The direct license agreement is the most effective way to organize technology transfer. In Article 1 Number 11 of the Patent Law, it is stated that, a license is a permit granted by a patent holder, both exclusive and nonexclusive, to the licensee based on a written agreement to use a Patent protected for a period of time and certainconditions. From the definition of a license according to the law mentioned above it can be stated that the license is permission to transfer rights exclusive from the licensor tolicensee. Next transfer the right is done with a agreement, namely a patent license agreement.

Understanding the license agreement according to Gunawan Widjaja is: A form of giving permission to utilize an Intellectual Property Right, which can be given by the licensor to the licensee, so that the license ecando a form of business activity, both in the form of technology or knowhow that can be used for produce, produce, sell or market certain (tangible) goods, which will be used to carry out certain service activities, byusing The licensed Intellectual Property Rights. For this purpose the licensee is required to provide counter achievement in the form of royalty payments also known as license fees._License agreement is a container as well as a document in which there are rights and obligations of the parties, namely the giver and the licensee to carry out an invention. The invention agreement must be made in writing and signedby both parties and contains information

about:

1. Date, month and year in which the license agreement was made;

2. Full name and address as well the signatures of the parties entered into a license agreement 3.Project license agreement

4. Term of the license agreement

5. Can or not have an extended license agreement,period

6. Implementation of licenses for all or part of exclusive rights

7. The amount of royalty and payment

8. Can or not the licensee gives more licenses continue to third parties 9. Limit the territory of the agreement lensi, if agreed upon;

10. Can or not the giver the license carries out itself licensed work. The patent license agreement has a large role in advancing national economy.

Optimizing the Implementation of the Patent License Agreement All efforts to optimize the implementation of patent license agreements need to be implemented. This is what it is has been described above, because the 
patent license agreement plays an important role in the framework of advancing the national economy, namely as a function of control and monitoring functions for the government in the field of technology, so that it then allows the implementation of technology description The following will explain what steps can be taken to optimize implementation patent license agreement, namely:

1. Register the license agreement using the Internet Based Registration System (IBRS) The purpose is to reform the mechanism for registering patent license agreements from those previously usedmanual system by registering directly at the Office of the Directorate General of Intellectual Property Rights at the Ministry of Law and Human Rightsbe using the system

2. Changing the system in patent licensing agreements Changing the system here is intended for remodel the system that has been set up but has not been effective to be implemented, so that later it will be realized optimization of the implementation of patent license agreements. patendi license agreement is given in the form of acknowledgment and guarantee of legal enforcement of patent licensing agreements. Patent license agreements will be legally recognized, in the sense that they are considered valid, if they fulfill certain conditions. In addition to the legal terms of the agreement, as stipulated in the Civil Code, the license agreement must also fulfill the requirements in the Patent Law, namely prohibition on loading clauses that could harm the Indonesian economy or load limiting restrictions the ability of the Indonesian people Patent license agreement play an important role in advancing the country's economy, namely as control and supervision of the government towards the transfer of technology in the country. Transfer of technology itself becomes important in order to develop the industry, which in its development becomes an important part in the progress of the economy of a nation.

\section{B. CONCLUSION}

Based on the results of the discussion above, the conclusions of this scientific work are:

1. Legal protection in the
C. ACKNOWLEDGEMENT

University Of Indonesia University Of Mitra Indonesia

Telkom University University Of Mellbourne

Saitama University 
D.

\section{EFERENCE(Based ISO 690 )}

[1] A. S. Putra And O. M. Febriani, "Knowledge Management Online Application In Pdam Lampung Province," In Prosiding International Conference On Information Technology And Business (Icitb), 2018, Pp. 181-187.

[2] A. S. Putra, O. M. Febriani, And B. Bachry, "Implementasi Genetic Fuzzy System Untuk Mengidentifikasi Hasil Curian Kendaraan Bermotor Di Polda Lampung," J. Sist. Inf. Dan Manaj. Basis Data, Vol. 1, No. 1, Pp. 21-30, 2018.

[3] O. M. Febriani And A. S. Putra, "Sistem Informasi Monitoring Inventori Barang Pada Balai Riset Standardisasi Industri Bandar Lampung," J. Inform., Vol. 13, No. 1, Pp. 90-98, 2014.

[4] Putra, Arie Setya. "2018 Artikel Struktur Data, Audit Dan Jaringan Komputer." (2018).

[5] Putra, A. S. (2018, July 17). Paperplain Fundamental Create Application With Borland Delphi 7.0 University Of Mitra Indonesia. Retrieved From Osf.Io/Pbrn9.

\section{E. REFERENCE (Based APA)}

Putra, A. S., Aryanti, D. R., \& Hartati, I. (2018, November). Metode SAW (Simple Additive Weighting) sebagai
Sistem Pendukung Keputusan Guru Berprestasi (Studi Kasus: SMK Global Surya). In Prosiding Seminar Nasional Darmajaya (Vol. 1, No. 1, pp. 85-97).

Sari, D. P., Febriani, O. M., \& Putra, A. S. (2018, November). Perancangan Sistem Informasi SDM Berprestasi pada SD Global Surya. In Prosiding Seminar Nasional Darmajaya (Vol. 1, No. 1, pp. 289-294).

Putra, A. S. (2018). Paperplain: Execution Fundamental Create Application With Borland Delphi 7.0 University Of Mitra Indonesia.

Putra, A. S., Sukri, H., \& Zuhri, K. Sistem Monitoring Realtime Jaringan Irigasi Desa (JIDES) Dengan Konsep Jaringan Sensor Nirkabel. IJEIS (Indonesian Journal of Electronics and Instrumentation Systems), 8(2), 221232.

Darmawan, A., Yuliawati, D., Marcella, O., \& Firmandala, R. (2016). Sistem Absensi dan Pelaporan Berbasis Fingerprint dan SMS Gateway. EXPLORE, 7(1).

Febriani, O. M., Wahyuni, T., \& Yusuf, S. (2017). DESIGN OF WEBSITE-BASED INFORMATION SYSTEM FOR EDOCUMENT ADMINISTRASI IN THE COMMUNITY SERVICE UNIT (A Case Study at Rajabasa District). INTERNATIONAL JOURNAL OF COMPUTERS \& TECHNOLOGY, 16(7), 7010-7020.

Febriani, O. M., \& Wahyuni, T. (2017, October). PERANCANGAN SISTEM 
E-DOCUMENT ADMINISTRASI LOGBOOK PENELITIAN PADA UNIT LAYANAN DI BANDAR LAMPUNG. In Prosiding Seminar Nasional Darmajaya (Vol. 1, No. 1, pp. 187-194).

Febriani, O. M., \& Permadi, A. B. (2017). Implementasi Sistem Aplikasi Data Bimbingan dan Pelanggaran Siswa pada Sekolah Menengah Atas di Lampung Tengah dengan Metode Analisis dan Desain Sistem Terdistribusi (SSAD). EXPERT, 7(1).

Febriani, O. M., \& Ambarwati, L. (2015). PERANCANGAN APLIKASI PENGOLAHAN DATA PENJUALAN UKM KELANTING KHAS TELO DESA SIDOHARJO KECAMATAN JATI AGUNG KABUPATEN LAMPUNG SELATAN. Jurnal Teknologi Informasi dan Bisnis Pengabdian Masyarakat Darmajaya, 1(1), 77-95.

Febriani, O. M. (2015). Rancang Bangun Aplikasi Ecommercemenggunakan Freewebstore pada UKM Kelanting di Desa Sidoharjo Lampung Selatan. Prosiding Sembistek 2014, 1(02), 446-458. 